\title{
Powder for Intravesical Suspension Dosage Form
}

National Cancer Institute

\section{Source}

National Cancer Institute. Powder for Intravesical Suspension Dosage Form. NCI

Thesaurus. Code C149834.

Solid preparation consisting of one or more powders intended to be dispersed in the specified liquid to obtain an intravesical suspension. 